\title{
First Record of Partial Albinism in two Catfish Species of Genidens (Siluriformes: Ariidae) in an Estuary of Southern Brazil
}

\author{
Mateus Evangelista Leal ${ }^{1 *}$, Uwe Horst Schulz ${ }^{1}$, Pablo Lehmann Albornoz ${ }^{1}$, Rodrigo \\ Machado $^{2}$ and Paulo Henrique Ott $^{3}$ \\ ${ }^{1}$ Laboratório de Ecologia de Peixes/Ictiologia; Universidade do Vale do Rio dos Sinos; Av. Unisinos 950; $93022-$ \\ 000; São Leopoldo - RS - Brasil. '2Laboratório de Ecologia de Mamíferos; Universidade do Vale do Rio dos Sinos; \\ Av. Unisinos 950; 93022-000; São Leopoldo - RS - Brasil. ${ }^{3}$ Universidade Estadual do Rio Grande do Sul; Unidade \\ do Litoral Norte; Rua Machado de Assis, 1456; 95520-000; Osório - RS - Brasil
}

\begin{abstract}
This study reports the first occurrence of partial albinism in two species of Ariidae: Genidens barbus and Genidens planifrons from an estuary of Southern Brazil. Possible causes of the simultaneous occurrence of three specimens with partial albinism are discussed, including random genetic alterations, chronic contamination effects and small effective population size, which may favor the expression of the recessive albino gene.
\end{abstract}

Key words: Estuarine fishes, Genidens barbus, Genidens planifrons, leucism

\section{INTRODUCTION}

Albinism is a genetic disorder produced by an autosomal recessive gene in the homozygous state caused by the deficiency in melanin production (Westerman and Birge 1978). The true albinism is recognized by the total lack of melanin, thus determining the pink or yellowish body color and red eyes (Sazima and Pombal-Jr. 1986). However, there is another form of depigmentation considered partial albinism (Sazima and PombalJr. 1986; Klug and Cummings 1999). A recent term, known as leucism, has also been introduced to the animals with abnormal skin pigmentation but normal eye color (Bechtel 1995). Recently, it has also been used in ichthyology (Clark 2002). In natural environment, there are several reports of total or partial albinism in freshwater fishes
(Westerman and Birge 1978; Sazima and PombalJr. 1986; Ueda et al. 2007; Jeffery 2009) and marine fishes (Béarez 2002; Simon et al. 2009; Piorski and Nunes 2010). Some cases of total or partial albinism in Siluriformes have been reported, e.g., Ictalurus punctatus (Westerman and Birge 1978), Trichomycterus itacarambiensis (Trajano 1997), Rhamdella minuta (Sazima and Pombal-Jr. 1986) Schizolecis guntheri (Brito and Caramaschi 2005), Ameiurus catus (Britton and Davies 2006) and Phreatobius cisternarum (Shibatta et al. 2007). Frequently captured albino fish are only reported in aquarium magazines and local newspapers (Sazima and Pombal-Jr. 1986). Catfish of the genus Genidens belongs to Ariidae family and comprises G. barbus (LACÉPÈDE, 1803), G. genidens (CUVIER, 1829), G. machadoi (MIRANDA-RIBEIRO, 1918) and G. planifrons

*Author for correspondence: mateusleal1977@gmail.com 
(HIGUCHI, REIS \& ARAÚJO, 1982). All the species inhabit coastal zones of South America (Marceniuk 2005; Marceniuk and Menezes 2007). $G$. barbus and G. planifrons occupy costal and estuarine areas and are occasionally found in lowland rivers covering the southernmost portion of South America (Marceniuk and Menezes 2007). Adult fishes of the Ariidae family migrate from the ocean to the estuaries to reproduce. Juveniles may stay in the estuary nursery areas for several years, before they return to the ocean (Reis 1986a; Reis 1986b). All the species are intensively exploited as fishery resources due to their high commercial value and large size. G. barbus may reach $1,200 \mathrm{~mm}$ of standard length and $G$. planifrons up to $711 \mathrm{~mm}$ (Marceniuk 2005; Milani and Fontoura 2007). This study describes the first record of partial albinism in three specimens of marine catfish of Genidens genus in an estuary in southern Brazil.

\section{MATERIALS AND METHODS}

Both Genidens species were collected in the estuarine Tramandaí-Lagoon, northern coast of Rio Grande do Sul State, Brazil (29 57'33,2"S; $50^{\circ} 09 ' 24,7 " \mathrm{~W}$; Fig. 1). The studied individuals were caught by professional fishermen from Imbé city, who took the specimens to the university because of their different appearance. The fishing gear used was gill nets of $500 \mathrm{~m}$ to $1000 \mathrm{~m}$ in length and $90 \mathrm{~mm}$ to $160 \mathrm{~mm}$ in mesh size. The captured catfishes were identified (according to Marceniuk 2005) and fixed in $10 \%$ formalin solution. The leucistic specimens were deposited in the Icthyological Collection of the Museu de Ciências Tecnológicas da Pontifícia Universidade Católica do Rio Grande do Sul (MCP), being identified as G. barbus (MCP 45723) and $G$. planifrons (MCP 45722 and 45724).

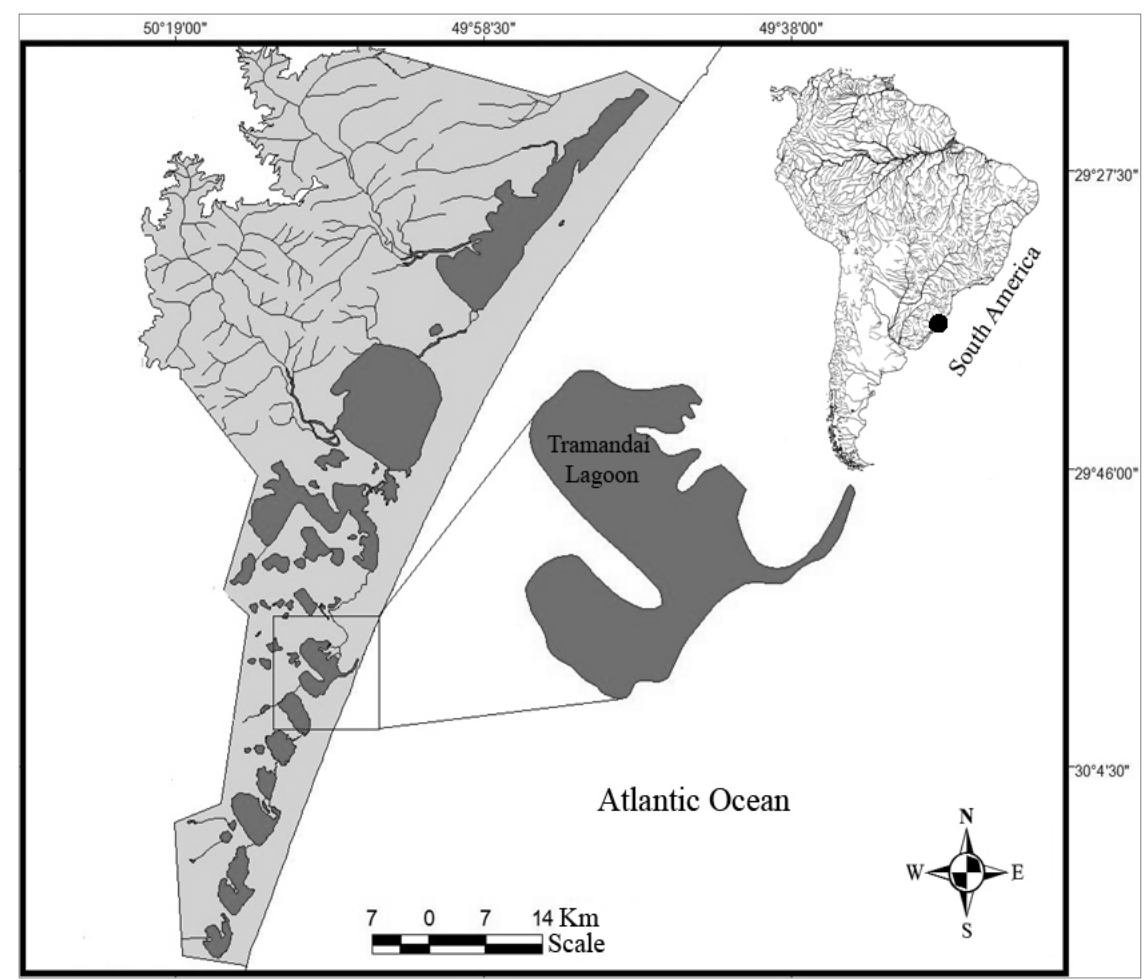

Figure 1 - Location of Tramandaí Lagoon.

\section{RESULTS AND DISCUSSION}

The first leucistic individual of $G$. barbus was captured in July 2008 (Fig. 2). In the same period, other two adult individuals of $G$. planifrons with the same abnormality were caught (Fig. 3). The eyes of both individuals were of normal color. One fish was prepared for human consumption, leaving only the head and spinal cord. These captures were the first documented evidence of partial albinism in the Ariidae family in an estuary of Southern Brazil. 


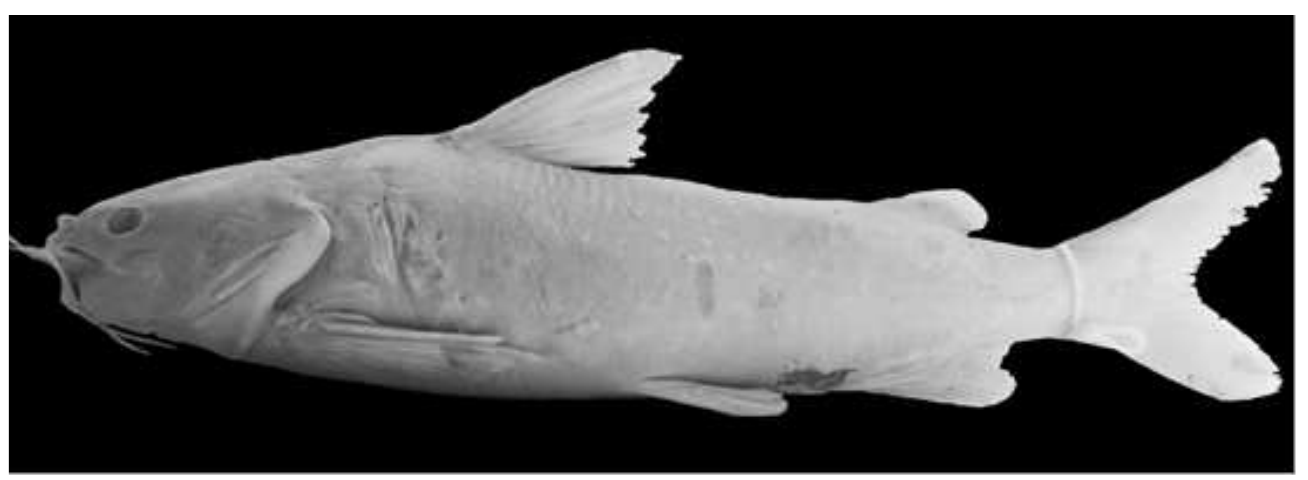

Figure 2 - A partial albino of Genidens barbus (picture after formalin conservation) with a normal eye color (83.4 cm total length).

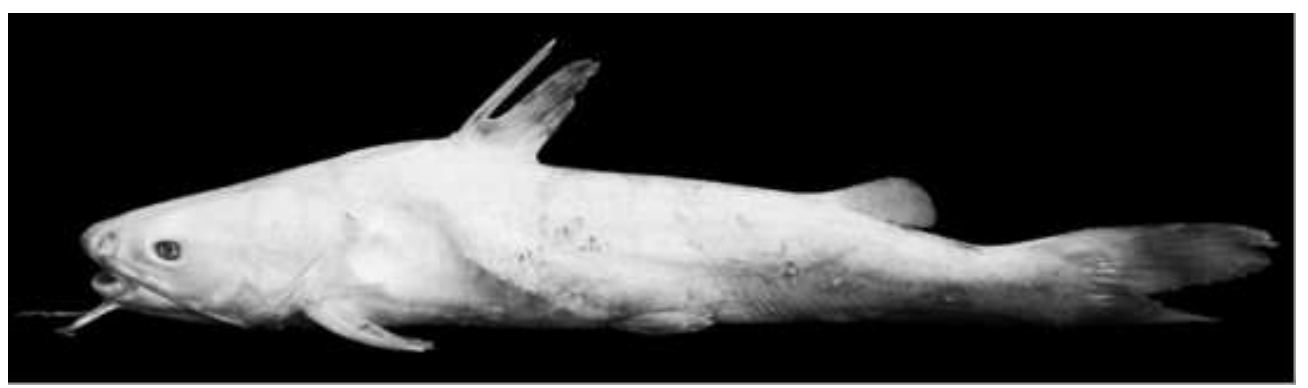

Figure 3 - A partial albino Genidens planifrons (natural conditions) with a normal eye color $(62.1 \mathrm{~cm}$ total length).

The occurrence of leucistic specimens of Siluriformes in the estuary might have been caused by three factors: (1) random genetic alterations, (2) contamination effects, or (3) genetic alteration due to small population size.

Random genetic events as cause for of the simultaneous occurrence of partial albinism in three individuals of two different species of catfish could not be excluded, although the probability might appear low. Random alterations might occur independently in each species.

The Tramandaí lagoon is located in a rural area dominated by rice plantations. The influx of halogenated hydrocarbons, organophosphorus compounds and heavy metals from chemical fertilizers cannot be excluded. All these groups of substances are known to influence the metabolism of ectothermic vertebrates (Fulton and Chambers 1985; Goldberg 1991; Stolyar et al. 2008). If contamination is present, it may act on chronic levels. However, acute problems like fish kills never were reported from this area. Water quality data available from the state agency FEPAM indicated that heavy metal concentrations were very low and, in most cases, below the detection level. In general, water quality was considered to be good (Haase et al. 2003).

The fishing pressure on marine catfish of this region has been high (Araújo 1988; Reis 1986a; Reis 1986b; Macahdo et al. 2012). Over the years, the lack of management of estuarine fish stocks increased the catch rate of the Ariidae family, which caused a decline in the abundance of the main species (Araújo 1988; Reis 1986a; Reis 1986b). This overfishing could have lead to a reduction of the effective population size, favoring the inbreeding and the expression of the gene for albinism (Sanabria et al. 2010). However, future studies on genetic variability of the marine catfishes in the region are needed to test this hypothesis.

The partial albino specimens may be more susceptible to predation than normal pigmented conspecifics. Pathological traits such as sensory or nervous deficiencies, anemia, low fertility, higher susceptibility to disease and poor vision may decrease the viability of albinos. Behavioral interactions with conspecifics may also be impaired (Acevedo and Aguayo 2008). Eventually, the accumulated occurrence of albino individuals 
may contribute to a further decrease of the already low population density.

Although the chromatic anomalies events recorded here might be result of random events, anthropogenic causes such as pollution and excessive fishing pressure might be involved, demanding a more thorough investigation of these aspects in the region.

\section{ACKNOWLEDGMENTS}

We thank Mr. Alberto Rocha and Mr. Osmar Morbach for donating the specimens for study.

\section{REFERENCES}

Acevedo J, Aguayo M. Leucistic South American sea lion in Chile, with a review of anomalously color in otariids. Rev Bio Mar Oceanogr. 2008; 43(2): 413-417.

Araújo FG. Distribuição, Abundância Relativa e Movimentos Sazonais de Bagres Marinhos (Siluriformes, Ariidae) no Estuário da Lagoa dos Patos (RS), Brasil. Revta Bras Zoo. 1988; 5(4): 09-54.

Béarez P. First record of albinism in a morey eel Muraena clepsydra (Muraenidae) from Ecuador. Cybium. 2002; 26: 159-160.

Bechtel HB. Reptile and amphibian variants: colors, patterns, and scales. Portland: Krieger Publishing Company; 1995.

Brito FG, Caramaschi EP. An albino armored catfish Schizolecis guntheri (Siluriformes: Loricariidae) from an Atlantic Forest coastal basin. Neotr Ichthyo. 2005; 3(1): 123-125.

Britton JR, Davies GD. First record of the white catfish Ameiurus catus in Great Britain. J Fish Biol. 2006; 69: 1236-1238.

Clark S. First report of albinism in the white-spotted bamboo shark, Chiloscyllium plagiosum (Orectolobiformes: Hemiscyllidae), with a review of reported color aberrations in elasmobranches. Zoo Biol. 2002; 21: 519-524.

Fulton MH, Chambers JE. Inhibition of neurotoxic esterase and acetylcholinesterase by organophosphorus compounds in selected ectothermic vertebrates. Pestic Biochem Phys. 1985; 23: 282-288.

Goldberg ED. Halogenated hydrocarbons: Past, present and near future problems. Sci Total Environ. 1991; 100: 17-28.

Haase J, Stringuini MH, Silva MLBC, Rodrigues MLK, Koch SMV. Qualidade das águas superficiais do Litoral Norte e Médio do Rio Grande do Sul. In: Saneamento Ambiental: Ética e Responsabilidade Social. Anais $22^{\circ}$ Congresso Brasileiro de Engenharia Sanitária e Ambiental; 2003 set; Joinville, Brasil. Associação Brasileira de Engenharia Sanitária e Ambiental; Joinville: ABES: 2003. p. 01-17.
Jeffery WR. Regressive evolution in Astyanax Cavefish. Annu Rev Genet. 2009; 43: 25-47.

Klug WS, Cummings MR. Conceptos de Genética. Madrid: Prentice-Hall; 1999.

Machado R, Ott PH, Sucunza F, Marceniuk AP. Ocorrência do bagre marinho Genidens machadoi (Siluriformes, Ariidae) na laguna Tramandaí, sul do Brasil. Neotrop biol cons. 2012; 7(3): 214-219.

Marceniuk AP. Chave para a identificação das espécies de bagres marinhos (Siluriformes, Ariidae) da costa brasileira. B Inst Pesca. 2005; 31(2): 89-101.

Marceniuk AP, Menezes NA. Systematics of the family Ariidae (Ostariophysi, Siluriformes), with a redefinition of the genera. Zootaxa. 2007; 1416: 1-126.

Milani PCC, Fontoura NF. Diagnóstico da pesca artesanal na lagoa do Casamento, sistema nordeste da laguna dos Patos: uma proposta de manejo. Biociências. 2007; 15(1): 82-125.

Piorski NI, Nunes JLS. A case of albinism in Batrachoides surinamensis (Batrachoidiformes: Batrachoididae) from north-eastern Brazil. Mar Biod Rec. 2010; 3: e99.

Reis EG. A pesca artesanal de bagres marinhos (Siluriformes, Ariidae) no estuário da Lagoa dos Patos (RS), Brasil. Documentos Técnicos de Oceanografia. Rio Grande do Sul: FURG: n5, 22p; 1986a.

Reis EG. Reproduction and feeding habitats of the marine catfish Netuma barba (Siluriformes, Ariidae) in the estuary Lagoa dos Patos, Brazil. Atlântica, 1986b; 8:3555.

Sanabria EA, Quiroga LB, Laspiur A. First record of partial albinism and scoliosis in Odontophrynus occidentalis Tadpoles (Anura: Cycloramphidae). Braz Arch Biol Tecnol. 2010; 53(3): 641-642.

Sazima I, Pombal-Jr JP. Um albino de Rhamdella minuta, com notas sobre comportamento (OstetheichthysPimelodidae). Rev Bras Biol.1986; 46(2): 337-381.

Shibatta OA, Muriel-Cunha J, Pinna MCC. A new subterranean species of Phreatobius goeldi, 1905 (Siluriformes, Incertae sedis) from the Southwestern Amazon basin. Pap Avul Zoo. 2007; 47(17): 191-201.

Simon T, Joyeux JC, Macieira RM. First record of partial melanism in the coney Cephalopholis fulva (Perciformes: Epinephelidae). Braz J Oceanogr. 2009; 57(2): 145-147.

Stolyar OB, Loumbourdis NS, Falfushinska HI, Romanchuk LD. Comparison of metal bioavailability in frogs from urban and rural sites of Western Ukraine. Arch Environ Contam Toxicol. 2008; 54: 107- 113.

Trajano E. Population ecology of Trichomycterus itacarambiensis, a cave catfish from eastern Brazil (Siluriformes, Trichomycteridae). Environ Biol Fish. 1997; 50: 357-369.

Ueda T, Ishnabe T, Jeon S-R. Establishment of an albino strain of the bitterling Tanakia signifer (Pisces, Cyprinidae). J Hered. 2007; 98(3): 277-279

Westerman GW, Birge WJ. Accelerated rate of albinism in channel catfish exposed to metals. Prog Fish Cult. 1978; 40(4): 143-146.

Received: October 10, 2011; Revised: July 10, 2012; Accepted: January 23, 2013. 